This PDF is a simplified version of the original article published in Internet Archaeology. Enlarged images, and interactive features which support this publication can be found in the original version online. All links also go to the online version.

\title{
Bulgarian Development-Led Archaeology in the Public Eye. Reception, Reactions, Possible Solutions
}

\section{Lyudmil Vagalinski and Milena Raycheva}

\section{Summary}

Can the public see the benefit of archaeology without an awareness of what archaeology does? The authors consider this question while exploring the evolution of Bulgarian society's view on development-led archaeological excavations over the past 30 years, by drawing on specific examples.

Media coverage of rescue archaeological work in Bulgaria is usually done in a dull, nonsystematic manner. Local archaeologists are neither trained for nor seem to fully grasp the necessity of active two-way communication with the public, particularly in the course of fieldwork. Moreover, project investors often impose restrictions on publicity, not realising that their business is losing out from such a secretive media policy. Nevertheless, some successful media projects have been carried out by a number of Bulgarian archaeologists in recent years and have significantly contributed towards society's increased knowledge and appreciation of archaeological work. The authors propose particular steps in order to accelerate and enhance this positive trend to keep the public informed and aware of the potential benefits of archaeology.

\section{Introduction}

In the context of discussing public benefit, the issue of archaeology's visibility to the public seems to be of paramount importance as it has a direct impact on the appraisal of archaeological work. This article focuses on Bulgaria's reception of - and reactions to development-led archaeology over the past 30 years in an attempt to analyse the weaknesses and the strengths of the current situation.

Public opinion about development-led archaeology in Bulgaria has changed dramatically. This complex process has been influenced mostly by modifications to the legislation and the media activity of archaeologists. 


\section{The period $1989-2009$}

Rescue excavations prompted by construction works - whether major infrastructure projects or smaller-scale urban investments - became established in Bulgaria following the painstaking political changes that started in November 1989. Various investors (state, private or municipal) began contracting archaeological institutions in order to conduct development-led excavations.

From the outset, it should be remembered that, according to Bulgarian law, archaeology is entirely state-controlled (Vagalinski 2018, 33; Vagalinski 2019). This ensures that all archaeological investigation - both regular and development-led - is carried out by state institutions, such as museums, universities, and the National Archaeological Institute. No private archaeological associations exist and scientific research, including excavations, may not be subject to tender since its results are considered of public benefit.

Considering this premise, it is not difficult to imagine that these early years were marked by tension between investors (developers) and archaeologists, causing mutual frustration. The investors often lost patience and violated contracts they had signed, especially in the case of large infrastructure excavations where finances were at stake and deadlines were crucial. As a result, several archaeological sites suffered from damage or even deliberate destruction during construction (Figure 1). In 2003, even the government itself put pressure on archaeological work and demanded that the duration of excavations along the Trakia Highway be reduced by half, despite an ongoing contract. Many construction companies refused to consider the archaeological results and carried on with their projects. In some cases, the archaeological institutions felt obliged to take legal action.

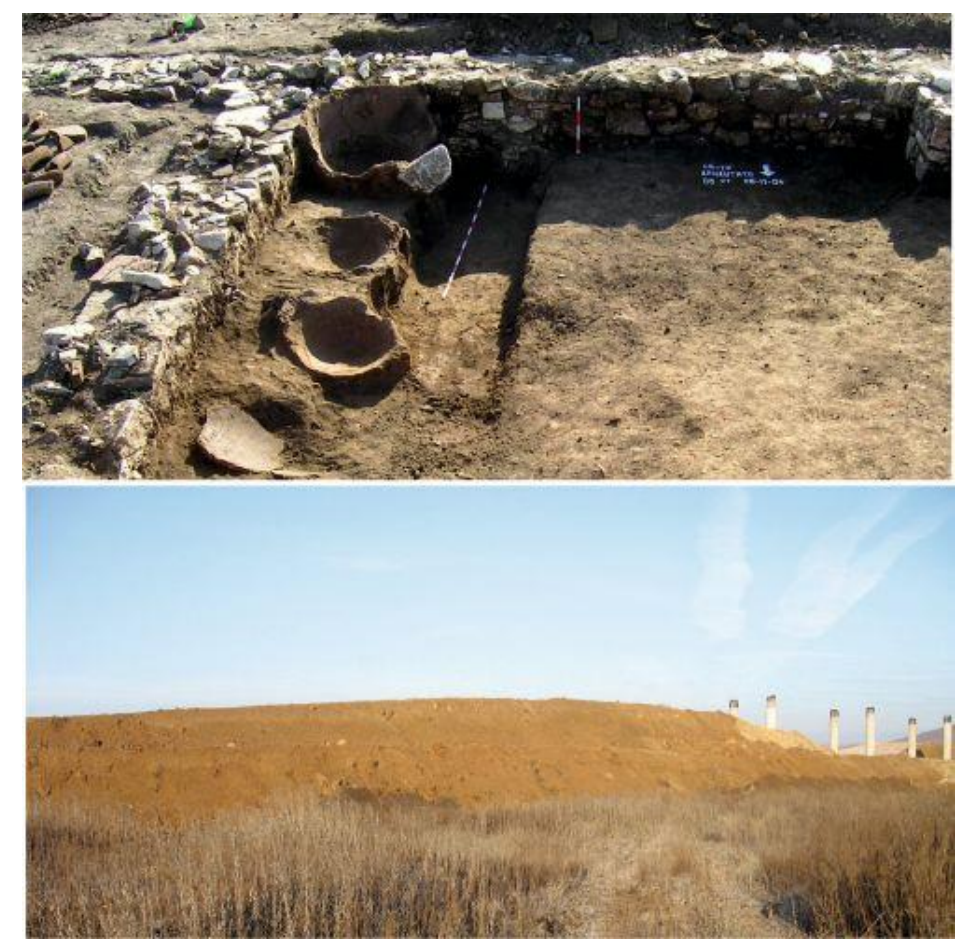

Figure 1: Villa rustica at Arnautito site destroyed by Trakia Highway infrastructure. Photos: L. Vagalinski 
These disagreements between stakeholders largely resulted from the lack of clear rules as to how precisely to calculate the cost of development-led excavations. In search of the cheapest options, the investors insisted on the establishment of tenders and attempted to turn archaeological institutions against each other in competition for offers. These initial years were also characterised by the investors dominating the media. They projected the idea that archaeologists were the ones who were slowing down key infrastructure projects (like Trakia and Maritsa Highways), thus depriving society.

The situation with urban development-led digs was worse, as they almost never received public attention and investors tried to intimidate archaeologists, breach contracts or even demolish sites secretly. A notorious example can be seen in Balchik, where an intact Cybele temple was severely damaged and partly covered in concrete by the investor, despite the attempts of local archaeologists to stop the construction of a modern building over it Footnote 1. Problems with investors were happening even in the heart of Sofia, next to government buildings, where the eastern half of the Late Roman amphitheatre of Serdica was partly destroyed by the construction of a hotel until finally, after some legal action, the investor agreed to incorporate it in the hotel. Footnote 2

Meanwhile, Bulgarian archaeologists were slow to realise the growing necessity of active communication, in their own words, with the media and society in general. There had been no such practice in Socialist Bulgaria to learn from. Moreover, publicity in the context of public construction works was regarded by many as unnecessary trouble and even potential disruption. During this period, which was economically difficult for most Bulgarians, society was more-or-less indifferent to rescue excavations and the issues that surrounded them. Aided by some archaeologists, the media gradually supported the message that excavations were justified only when they yielded attractive finds, particularly sensational gold. Footnote 3 What is more, it was perceived that the sole purpose of archaeology is to produce such artefacts, and their value seemed to be the only recognisable aspect of public benefit.

\section{Post-2009}

The situation began to change towards a more-or-less positive direction after an amended Cultural Heritage Act was passed in 2009. Footnote 4 Another step forward was achieved with the 2011 Decree for conducting field archaeological research. Footnote ${ }_{5}$ Furthermore, The National Archaeological Institute with Museum, Sofia University and the Association of Bulgarian Archaeologists played a key role in the creation and publication of a detailed tariff that determined the costs for all aspects of excavations, published in the State Gazette in 2012. Footnote 6 Gradually, these legal documents started to bear fruit. The tariff eliminated the bone of contention for archaeologists and investors. It also put an end to the main instrument for the manipulation of public opinion at the expense of archaeologists and archaeological heritage. A year after the publication of the tariff, the Director of the National Archaeological Institute with Museum sued the State Road Agency for trying to go around it and prevailed on the claim before the Commission on Protection of Competition and in the Supreme Administrative Court.

Around the same time, archaeologists started to communicate with the public. The heads of the National Archaeological Institute with Museum and the Department of Archaeology in Sofia University actively sought media attention and organised press conferences dedicated to excavations. The National Archaeological Institute with Museum started organising annual archaeological exhibitions displaying the most 
attractive finds from the previous year, particularly from large infrastructure sites. $\frac{\text { Footnote }}{\text {. }}$ $\geq$ These events were accompanied by press conferences and award ceremonies to acknowledge the work of journalists who reported the achievements and problems of Bulgarian archaeology throughout the year. The multiple interviews surrounding the legal case against the State Road Agency led to a clearer idea in Bulgarian society about the public benefit of archaeology and rescue excavations in particular. The public no longer talked about artefacts and increasingly the discourse involved the long-term effects of archaeology - people started discussing topics such as preservation, tourist capacity, accessibility etc.

This period also gradually influenced the attitude of politicians and investors. Earlier, politicians reproached archaeologists, accusing them openly about the delays in infrastructure projects, presenting their work as a nuisance and the results from it as uninteresting stones and pots. Their tone eventually became softer and this rhetoric was abandoned. Footnote 8 Archaeologists are no longer blamed and there is a tendency among politicians to demonstrate respect and interest in findings. Moreover, showing moral and financial support for excavations seems to have a more favourable effect on the politicians' public image.

\section{Today}

Bulgarian society is now more-or-less updated on the results of the regular (planned) excavations. A growing interest is observed in some sites with a constant flow of visitors - a good example can be seen in the regular excavations of Heraclea Sintica (Figure 2). Very often, the appreciation is so high that it engenders unrealistic expectations of fast financial benefit from tourism, on several levels (government, municipalities, or the wider public).

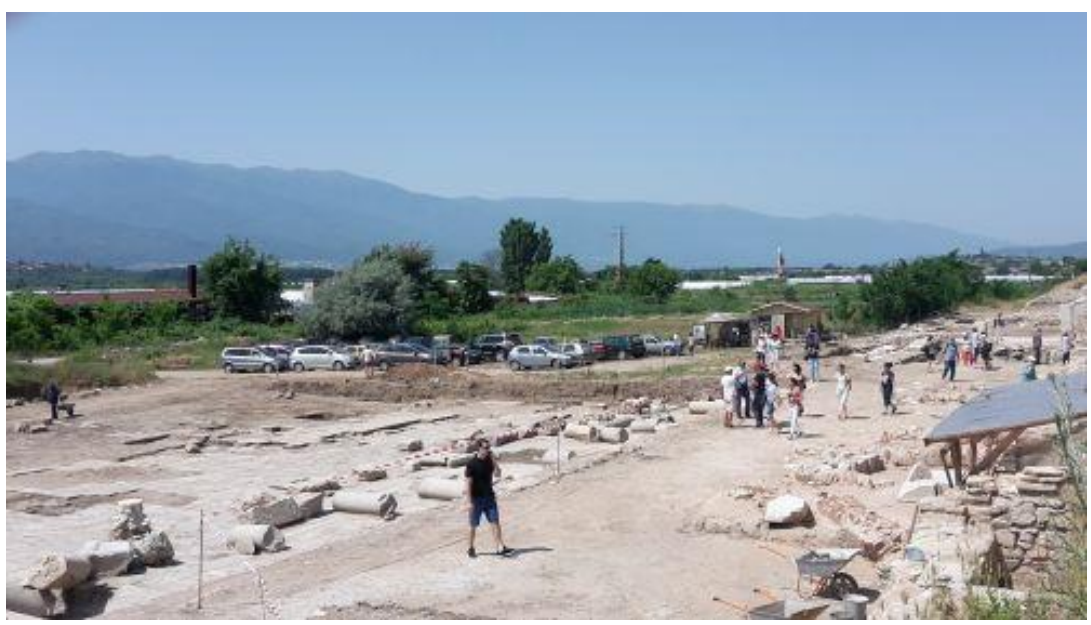

Figure 2: Tourists visiting the excavations at Heraclea Sintica in summer 2019. Photo: L. Vagalinski

However, there is still much to be desired concerning rescue excavations, both in terms of large infrastructure and urban archaeology. The number of rescue excavations compared to that of regular digs is increasing all the time. If in the first 20 years after 1989 the number of development-led excavations was much lower, later they were more balancedl, and in 2019 the ratio is almost 3:1 (394:141) in favour of development-led digs (Figure 3). This clearly defined pattern demonstrates that rescue excavations need 
much more media coverage, requiring the presence of Bulgarian archaeologists in the public eye.

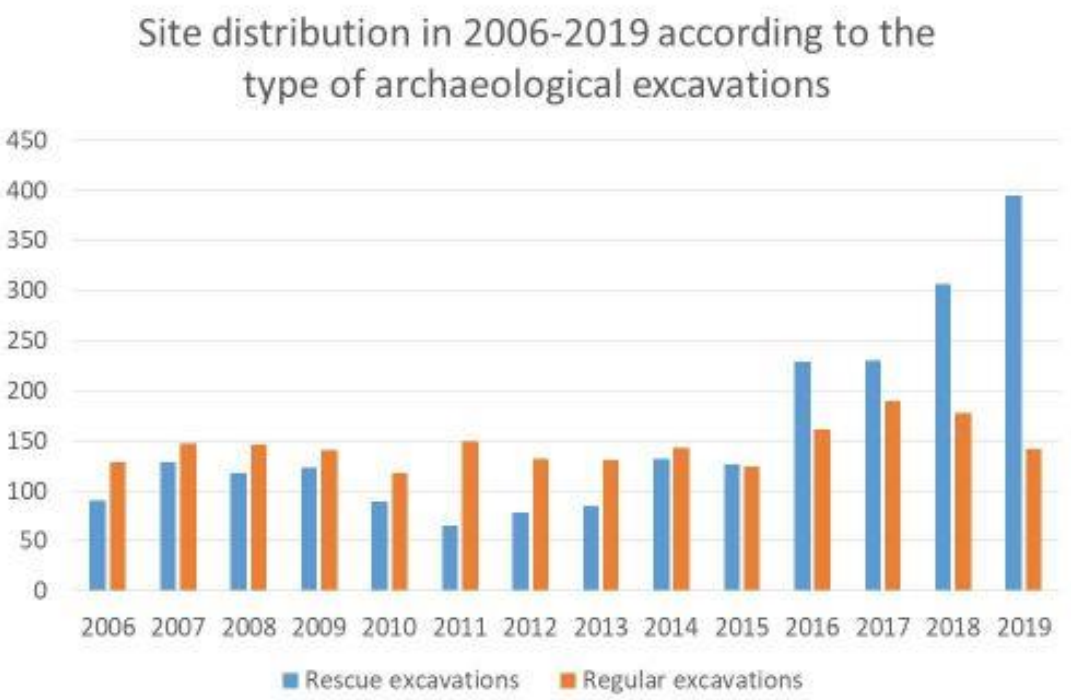

Figure 3: Site distribution of regular vs development-led excavations in Bulgaria, 20062019. Statistics source: NAIM-BAS

This is also visible in terms of the money flowing into various archaeological institutions, demonstrated by the statistics of the National Archaeological Institute with Museum over the past seven years (Figure 4). The greater income from development-led projects means greater responsibility to the public and therefore more open communication.
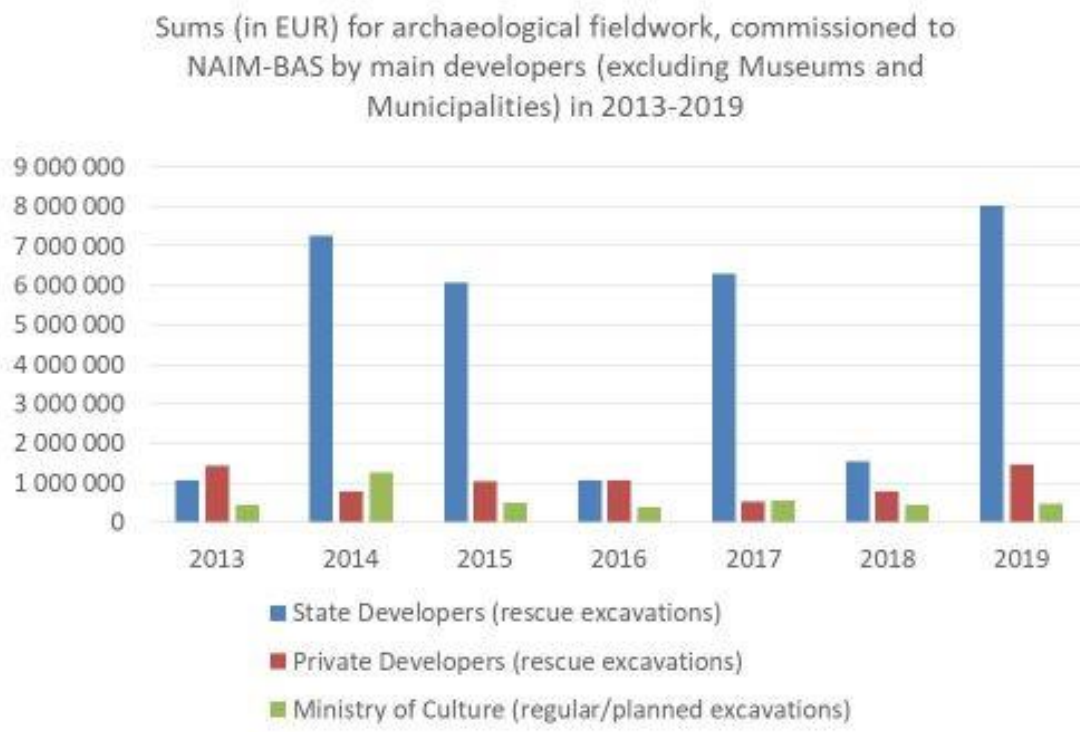

Figure 4: : Income (in EUR) for NAIM-BAS by types of developers, 2013-2019. Statistics source: NAIM-BAS

In urban development-led archaeology, things seem to have improved, although they are far from perfect. An important role nowadays is played by social networks, particularly local websites. They are alerted to developments in the cities, engage in discussions about the future of their heritage and are usually in favour of the 
archaeologists if there are conflicts with investors. There have been several positive examples in recent years in cities with a rich cultural heritage such as Plovdiv, now the second largest city in Bulgaria, and descended from the major Roman town of Philippopolis. Eootnote 9 After long and problematic discussions, the development-led works in the centre of Sofia also came to a more reasonable dialogue and eventually a positive outcome, with society and media actively engaged in the issues. The ruins of ancient Serdica are now displayed in situ in and around Sofia's metro, covering over $9000 \mathrm{~m}^{2}$. Footnote 10

Infrastructure rescue excavations are still reported in the media inconsistently however. Bulgarian society has no idea about the legal framework, or the potential benefit from such excavations. The public mostly hears about them in news related to politicians inspecting the sites and rarely shows a special interest in them.

However, the public seem to be eager for news about these major projects and are willing to discuss the future of cultural heritage as a public benefit, as we recently learned during the construction of Struma Highway when an archaeological site became infamous. After seven months of indifference to the site by the locals and vague interest from the media, there was an unexpected reaction: society misinterpreted the information and accepted the idea that an important ancient settlement, known from sources as Scaptopara, was being deliberately destroyed by the archaeological institutions in order to build a highway. The archaeologists did little to clarify the situation. This generated a massive reaction on Facebook by all kinds of social groups, $\frac{\text { Footnote } 11}{\text { to }}$ the signing of petitions and protests on site during the ongoing excavations. The archaeologists were vilified for doing their job, accused of corruption and held responsible for the future fate of the site, and their expertise on the identification or the exhibition value of the finds was entirely disregarded.

This came to emphasise the importance of not only how much archaeologists talk about what they find, but also how they talk to the public. Sometimes investors include a confidentiality clause in the contracts of infrastructure excavations. At the same time, even when archaeologists are not advised to restrain from interviews, they lack training in how to communicate to society and the media. Many archaeologists still believe that 'less information is less trouble'. Some go in an entirely different direction, by sharing with the media sensational or inappropriate statements. $\frac{\text {.ootnote } 12}{2}$ In either of these cases no information at all or inappropriate information - the public reacts with mistrust regarding the professional skills of the archaeologists, and is ultimately confused regarding the value of the heritage.

Over the last few years, some Bulgarian archaeologists have been trying to fill the media vacuum. An important role was played by the 'Journey to The Past' series on Bulgarian National TV, , Footnote 13 which offered an insight to the excavations and gave the opportunity for archaeologists to explain the sites in their own words. This show significantly improved the image of archaeologists in the public eye, drawing more attention to the hard work involved and the value of discoveries beyond attractive finds.

Inevitably, the role of TV, radio and printed publications has subsided in the recent decade and digital platforms are playing a much greater role. While the websites of institutions like museums and universities still seem outdated and slow in meeting the demands of the modern public, other, usually non-institutional platforms relying mostly on social media, are quickly attracting audiences. 
A successful example gaining popularity among Bulgarian and foreign audience can be seen in the Archaeology in Bulgaria blog with over 12,000 followers and several articles in English on a variety of topics, covering ongoing sites, new discoveries and actual problems of Bulgarian archaeology.

Probably the best known and most influential e-platform dealing with archaeology in the country is Archaeologia Bulgarica, whose motto is 'See the discoveries as they happen'. Footnote 14 While it has not covered development-led excavations yet, it is nevertheless noteworthy as its success may point to a possible solution to the visibility problem which development-led archaeology is facing nowadays everywhere. The main goal of the platform is to allow the wider audience to experience what it is like to be a member of the archaeological teams on the field. By taking the viewer on video walks through sites, it rapidly attracted more 10,000 followers from around the world, and the news reached hundreds of thousands. ${ }^{\text {Footnote } 15}$ One of its achievements was a livestream from the site, broadcasting to children and parents in the Interactive Children's Science Centre Muzeiko in Sofia. Footnote 16 Parallel to this, the platform created an educational board game 'Archaeologists vs Treasure hunters' in Bulgarian and English, which is gaining popularity in the country and abroad (Figure 5).

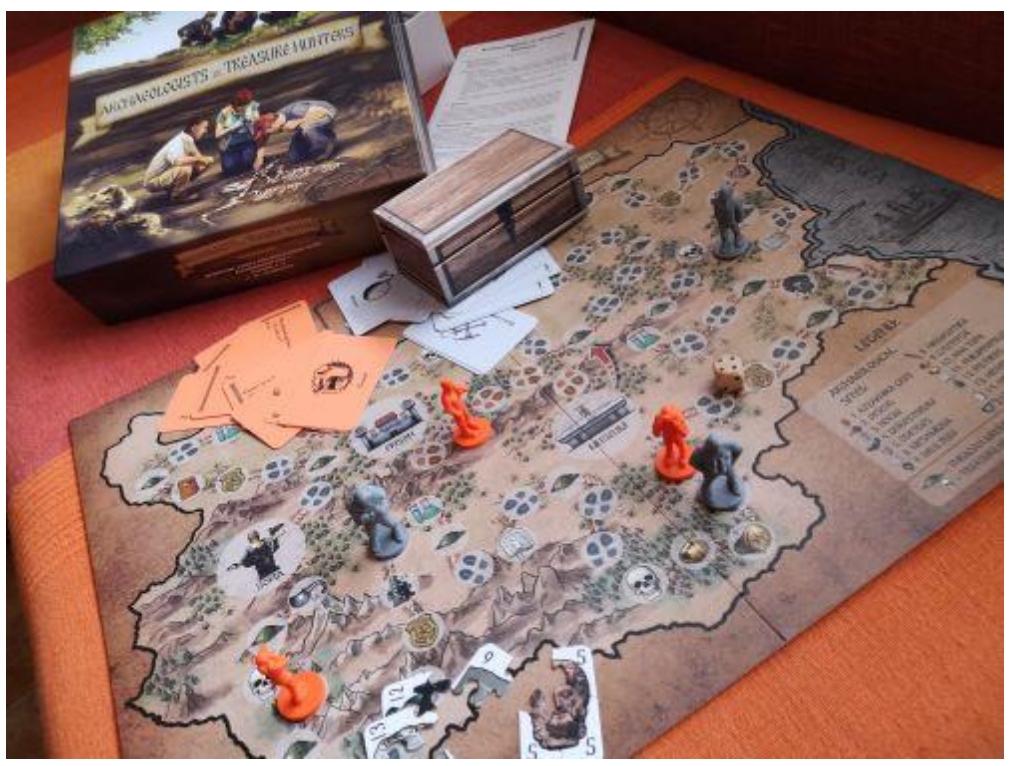

Figure 5: 'Archaeologists vs Treasure-Hunters' board game. Photo: www.archaeologiabulgarica.com

\section{Conclusion and Suggestions}

This short overview shows that the legislative framework has changed much development-led archaeology in Bulgaria, but another important role is played by the public image of the archaeologists as seen through the media. There is still a lot to be done in terms of communication, which can influence to a great extent whether the public regards archaeology as a benefit at all. While some archaeologists are already finding successful formulae to maintain a fruitful contact with the audience, there is still an urgent need for guidance and training.

It therefore seems reasonable to put forward two suggestions that may be helpful not only for Bulgaria but for all archaeologists in Europe. Firstly, it seems crucial to develop, 
with the help of EAC, a digital and accessible guide for archaeologists to help them in their contacts with the media and society (adults and children) during and after development-led excavations. Naturally, the guide should consider some important features such as consistency, appropriate language and measures for a problem-free experience. Secondly, it seems necessary to create a European archaeological information network to combine e-media platforms specialising in 'insider's knowledge' archaeological news that would undoubtedly be of great benefit both for archaeologists and the public all over Europe and would help understand and value our common heritage better.

\section{Footnotes}

1. 'Cybele's temple in Balchik was covered in concrete', 19.05.2007. https://news.bg/regions/zalyaha-s-beton-hram-na-boginyata-kibela-v-balchik.html $\longleftarrow$

2. Arena di Serdica Hotel (venue of the 18th Annual EAC Symposium), now proudly displays the ruins and advertises them as the main highlight, emphasising its own role in financing the excavations: https://www.arenadiserdica.com/pages/the-amphiteater-of-ancient-serdica $\longleftarrow$

3. 'After a 25-century old golden mask, the archaeologists are expecting to find a royal tomb',

22.08.2004. https://www.dnevnik.bg/dnevnikplus/2004/08/22/168351 sled zlatna maska na 25 veka arheolozite ochakvat i/ $\leftrightarrows$

4. State Gazette, issue $19,13.03 .2009$, active since 10.04 .2009 , with several amendments until today. $\longleftarrow$

5. State Gazette, issue 18, 01.03.2011; Decree for conducting field archaeological research of

14.02.2011: https://dv.parliament.bg/DVWeb/showMaterialDV.jsp;jsessionid=9C2E15A8D713EF93FCBA117D45147DB3?idMat=45279 $\leftrightarrows$

6. State Gazette, issue 30, 17.04.2012; the Decree of 14.02.2011 is appended with a 'planned budget' table, elaborating types of costs and formulae for their calculation: https://dv.parliament.bg/DVWeb/showMaterialDV.jsp;jsessionid=FC955F02322DFD40DACAF6ACA1C9A29F?idMat=63396 $\longleftarrow$

7. The annual exhibitions largely feature artefacts from infrastructure excavations - see for instance '3D Virtual Tour of the Thirteenth National Exhibition Bulgarian Archaeology 2019': http://naim.bg/bg/content/category/1234/116/ $\leftrightarrows$

8. Cf. 'Bulgarian PM shocks archaeologists with insulting treatment', 11.01.2012, when archaeologists are reprimanded for working too slow in winter conditions. https://www.novinite.com/articles/135624/Bulgarian+PM+Shocks+Archaeologists+with+Insulting+Treatment and 'Premier Boyko Borissov visits largest burial mound....', 28.08.2019, when archaeologists are 'greeted for their excellent job'. https://bnr.bg/en/post/101160326/premier-boyko-borissovvisits-largest-burial-mound-in-the-balkans-near-the-village-of-manole $\longleftarrow$

9. 'Prominent businessmen destroyed priceless ancient mosaics', 15.12.2019 - https://plovdivnow.bg/plovdiv/krupni-biznesmeni-unishtozhiha-beztsenniantichni-mozaiki-27572

10. 'Sofia's ancient Serdica archaeological complex opens', 20.04.2016. https://sofiaglobe.com/2016/04/20/sofias-ancient-serdica-archaeological-complexopens/ $\longleftarrow$

11. 'Funerary procession and human chain for the salvation of Scaptopara', 19.07.2018 - https://www.kmeta.bg/traurno-shestvie-i-jiva-veriga-zaspasyavaneto-na-skaptopara $\longleftarrow$

12. Most frequently, commenting on the market value of artefacts or equating them to modern-day prestige goods, e.g. luxury cars. $\longleftarrow$

13. The show has visited most of the major excavated sites in Bulgaria, with host Maria Cherneva interviewing the archaeologists on the spot; cf. Journey to the Past: A Sanctuary of Demeter and Persephone, 31.08.2016 - https://www.bnt.bg/bg/a/patuvane-v-minaloto-svetilishte-na-demetra-i-persefona $\longleftarrow$

14. Archaeologia Bulgarica is an NGO created in 2015, in connection with a peer-reviewed scientific magazine of the same name. Since 2018 , its e-platform - a website and several accounts on social media - specialises in archaeological news in Bulgarian, English and Russian. It offers video walks, short movies and articles about several sites in Bulgaria; its most acclaimed feature is broadcasting live from ongoing excavations - https://www.archaeologiabulgarica.com/en/ $\longleftarrow$ 
15. A good example of the platform's interactive approach can be seen in a short 2-minute video taken with an archaeologist's phone on 14.09 .2019 in Heraclea Sintica https://www.facebook.com/watch/live/?v=495901774289527\&ref=watch permalink. It was viewed by 9000 people, shared by 108 , and was liked by 567 . The comment section was rather active, with viewers asking questions with respect and archaeologists responding quickly. $\longleftarrow$

16. 'First livestream Muzeiko - Heraclea Sintica' was an event that took place on 13.09 .2019 and was also hosted on the Facebook page of Archaeologia Bulgarica. https://www.facebook.com/events/2400894340181728/ It was pre-advertised by the National Radio and popular news website and received much acclaim. $\longleftarrow$

17. 'New board game pits archaeologists against treasure hunters...', 14.12.2018 - http://archaeologyinbulgaria.com/2018/12/14/new-board-game-pitsarchaeologists-against-treasure-hunters-in-archaeological-sites-all-across-bulgaria/ $\longleftarrow$

\section{Bibliography}

Vagalinski, L. 2018 'Making choices in archaeological heritage management. The case of Bulgaria' in A. Degraeve (ed) Proceedings of the International Conference, Athens, Greece, 9-11 March, 2017, EAC Occasional Paper 13. Namur/Belgium, 3336. https://www.europae-archaeologiae-consilium.org/eac-occasional-papers

Vagalinski, L. 2019 'A decade of development-led archaeology in Bulgaria', Internet Archaeology 51 https://doi.org/10.11141/ia.51.4 